\title{
身の周りの電磁界と 人の健康への影響
}

6 電界, 磁界, 電界曝露, 磁界曝露, 生体影響, 健康影響

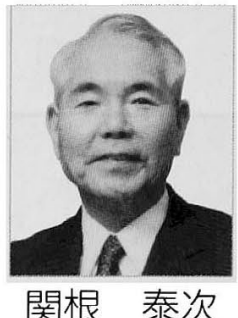

\section{1.まえがき}

電気学会では 1995 年 12 月に「電磁界生体影響問題調査 特別委員会」(以下「特別委員会」) を発足させ，電磁界か 人の健康に影響するかどうかについて，これまでの研究状 況を調査し，総合的に評価を行ってきた。そして 1998 年 10 月に報告書「電磁界の生体影響に関する現状評価と今 後の課題」をまとめ, 発行した。その結論は「電磁界の実 態と実験研究で得られた成果をもとに評価すれば，通常の 居住環境に打ける電磁界が人の健康に影響するとはいえな い」というものである。

「特別委員会」には総合的な評価ができるように，電気 工学および医学・生物学の両分野の専門家に参加願った。 具体的な検討は, 主として電気工学的側面から, 身の周り の電磁界の実態や測定法, 解析法について調査・評価する 「第 1 作業部会（主查 宅間董京都大学教授）」と，主とし て医学的側面から，生体に対する影響の問題，細胞や生物 に対する研究について調査・評洒する「第 2 作業部会（主 查上野照剛東京大学教授)」において行われた。

電磁界の健康への影響の問題が話題にされるようになつ たのは，1979 年にアメリカのウェルトハイマーとリーパ 一が配電線と小児がんに関する疫学研究の結果を発表し, 配電線近傍に住む子供に白血病の発生率が高いことを示唆 したのがきっかけである。また 1992 年にはスウェーデン のカロリンスカ研究所のフェイチングとアールボムが磁界 と小児白血病の関連性を示唆した。

このような疫学研究の結果による問題提起をきっかけと して，その後世界各国のさまざまな機関で研究が進められ るようになり，現在までにWHO（世界保健機関）を初め

せきね・やすじ (正員) 1959 年東京大学大学院数物系研究 科博士課程修了。同年同大学電気工学科勤務。講師, 助教授, 教授を経て平成 4 年退官。同年東京理科大学工学部教授。電力 システム工学の研究に従事。平成元年電気学会会長, 日本学術 会議会員 $(15 ， 16 ， 17$ 期)，スウェーデン王立工学アカデミー 会員。電気学会電磁界生体影響問題調査特別委員会委員長。
主要な国際機関や公的機関で総合的な調査・評価が行わ れ，ガイドラインなども発表されている。それらの評価結 果は，電磁界が健康に影響を与えるということを認めるも のはないが，科学的なデータの蓄積が不可欠であることか ら，今後もさらに研究を進める必要があると述べている。

この問題は電気工学と医学・生物学の両方の分野にまた がる学際的な領域にあり，しかも疫学研究の結果を評価す るには統計数学の素養も必要となるなど, 問題を理解する には幅広い専門知識と評価能力を必要とする。

社会一般に正確な情報や知識を広め，正しい理解を深め ることは，電気学会の役割の一つであり，「特別委員会」 では調查・評価活動に加えて，一般の方を対象に「電磁界 の健康影響に関するシンポジウム」の開催や，ホームペー ジ (http://www.iee.or.jp/) の開設により，分かりやすい 説明を提供するように努めている。本解説もそのような観 点から，限られた紙面であるが，問題の核心を平易に解説 するようにしたい。

なお，「特別委員会」では，居住環境を初めとして人が 通常遭遇する電磁環境を中心に，主として直流を含んだ $300 \mathrm{~Hz}$ までの極低周波数領域（ELF）の電磁界を検討の 対象とした。

\section{2. 疫学研究について}

\section{1 疫学研究とは}

電磁界の健康への影響について問題を提起したのは疫学 研究である。疫学研究というのは人の集団を対象にして, 発生した病気と，その原因と想定される要因との関連性 を，統計学的に調查する学問である。具体的には複数の集 団の間で, 病気の発生に差があるかどうか, 病気の発生に 影響すると想定される要因（環境などの条件）に差がある かどうかを調査し，その差が統計学的に偶然起こり得る以 上のものであるかどうか（有意であるかどうか）を評価し て, 要因と病気の関係を推測するというものである。 病気に関する研究を人体を用いて，実験として行うこと はできないので, 疫学研究が貴重な情報を提供していると 
表 1 電界・磁界曝露と小児がんに関する研究での結果の例

\begin{tabular}{|c|c|c|c|c|c|c|c|}
\hline \multirow{2}{*}{ 研究者 } & \multirow{2}{*}{ 曝露評価 } & \multicolumn{2}{|c|}{ 白血病 } & \multicolumn{2}{|c|}{ 脳腫瘍 } & \multicolumn{2}{|c|}{ 全がん } \\
\hline & & RR & $95 \% \mathrm{CI}$ & RR & $95 \% \mathrm{CI}$ & $\mathrm{RR}$ & $95 \% \mathrm{CI}$ \\
\hline Wertheimer (1979) & ワイヤコード & 3.0 & $1.8 \sim 5.0$ & 2.4 & $1.2 \sim 5.0$ & 2.2 & $1.6 \sim 3.1$ \\
\hline Feychting (1993) & 磁界測定値 ( $\geqq 0.20 \mu \mathrm{T})$ & 0.6 & $0.2 \sim 1.8$ & 1.5 & $0.4 \sim 4.9$ & 0.9 & $0.5 \sim 1.7$ \\
\hline Olsen (1993) & 磁界計算值 $(\geqq 0.25 \mu \mathrm{T})$ & 1.5 & $0.3 \sim 6.7$ & 1.0 & $0.2 \sim 5.0$ & 1.5 & $0.6 \sim 4.1$ \\
\hline Savitz (1993) & ワイヤコード & 2.9 & $1.5 \sim 5.5$ & 2.5 & $1.1 \sim 5.5$ & 1.9 & $1.1 \sim 3.2$ \\
\hline Verkasalo (1993) & 磁界計算值 $(\geqq 0.20 \mu \mathrm{T})$ & 1.6 & $0.3 \sim 4.5$ & 2.3 & $0.8 \sim 5.4$ & & \\
\hline Coghill (1996) & 電界測定值 $(>20 \mathrm{~V} / \mathrm{m}$ ) & 4.7 & $1.2 \sim 27.8$ & & & & \\
\hline Gurney (1996) & ワイヤコード & & & 0.9 & $0.5 \sim 1.5$ & & \\
\hline Preston-Martin (1996) & ワイヤコード & & & 1.2 & $0.6 \sim 2.2$ & & \\
\hline Linet (1997) & 磁界測定值 $(\geqq 0.20 \mu \mathrm{T})$ & 1.2 & $0.9 \sim 1.8$ & & & & \\
\hline Michaelis (1997) & 磁界測定值 $(\geqq 0.20 \mu \mathrm{T})$ & 3.2 & $0.7 \sim 14.9$ & & & & \\
\hline Tynes (1997) & 距離 $(<51 \mathrm{~m})$ & 0.6 & $0.3 \sim 1.3$ & 0.8 & $0.4 \sim 1.6$ & 1.3 & $0.9 \sim 1.8$ \\
\hline
\end{tabular}

いえる。しかし, 実際に生活している人間の環境条件は複 雑多岐であり，長期間にわたって特定の要因だけに差があ る集団を設定することは，実際上不可能なことである。

疫学研究によって提起される問題は, 断定的, 確定的な 結論ではなく, 問題の存在の可能性を示唆するにすぎな い。すなわち, 疫学研究だけでは因果関係を確定すること はできないわけで, 疫学研究が示唆した内容は, ほかの実 験的研究によって因果関係が確認され, 初めて意味のある 結果となるのである。

\section{2 電磁界環境に関する疫学研究}

電磁界と人の健康との関連性に関して, 欧米で多くの疫 学研究の結果が発表されている。「特別委員会」では 1991 年以降に発表された磁界曝露と悪性疾病に関する査読付き 論文 83 件を取り上げて調査・評洒した。これらの中には, (1) 居住環境と小児の悪性疾病，（2）居住環境と成人の悪 性疾病, (3) 親の電磁界曝露と小児の悪性疾病, (4)職業 曝露と悪性疾病, に関するものが含まれている。

表 1 に居住環境での電磁界曝露と小児の悪性疾病につい ての調査結果の例を示す。この表にあるように疫学研究の 結果は統計的な解析から得られた数值として与えられる が, 数值から直ちに関連性の有無を判断するのではなく, 統計学的な意味を読み取る必要がある。表でRR（Relative Risk）は関連性の程度を表すもので相対危険比とい われ，この数值が大きいほど関連性の程度が高いことを示 している。関連性の評価には RRの精度も考慮しなければ ならない。その $95 \%$ 信頼区間を示しているのが $95 \% \mathrm{CI}$ (Confidence Interval) である。この 95\%CIの幅が狭い ほど推定值の精度は高く, 広いほど精度は低いということ になる。対象症例数が多いほど, 精度は高くなるが, まれ な病気では症例数が少なくなり, 精度が低下する。そこに 疫学研究の難しさがある。

報告を調査・比較すると, 中には送電線の存在と小児白
血病とに弱い関連性が認められるとの報告もあるが, 同じ 疾病について，関連性があるという報告もあれば，関連性 はみられないとする報告があるなど，結果に一貫性が認め られないという問題がある。

一方, 磁界への曝露状態の評価方法には, ワイヤコード (配電線までの近接度と電流の大きさで分類したもの), 送 電線・電力施設汃らの距離, 磁界計算值, 屋内や作業環境 での磁界の測定值, あるいは職種（職業曝露の場合）が取 り上げられているが, ワイヤコードが家庭内で直接測定し た磁界の值と関連していないなど, 曝露の実態が十分把握 されているとはいえない。

ここで改めて述べたいことは, 疫学のデー夕は対象とし た集団に有意な差があるかどうかを示しているが，その差 の原因については推定をしているだけで，例えば電磁界と の関連性を直接的，断定的に示しているわけではないとい うことである。したがって, 後に述べる生物学的実験研究 による確認が必要となるのである。

\section{3. 身の周りの電磁界}

\section{1 電磁界の発生}

電磁界と人の健康の関連性を評価するためには, 身の周 りの電磁界の大きさを定量的に把握することが必要であ る。電磁界には人為的に発生するものだけでなく, 自然界 にもともと存在するものがある。自然界に存在する電界は 大気電気のほ力, 雷雲, 雷放電, 生体電気, 摩擦・剥離に 上万带電から生じ, 磁界は地磁気, 磁石, 牛物磁石, 雷放 電などから発生する。表 2 にそれらの典型的な数值を示 す。

人為的に電磁界を発生するものは多種多様存在するが, 送電線の例を紹介する。送電線からの電磁界は周波数が 50 ないし $60 \mathrm{~Hz}$ である。電界に関しては静電誘導による 人への感知を防止する観点から, 送電線下の電界強度を人 
の往来のまれな場所を除いては $3 \mathrm{kV} / \mathrm{m}$ 以下に押さえる ように設計されている(詳細は後述)。磁界の大きさは送 電線からの距離の 2 3 乗のオーダで減衰するが, 減衰の 程度は送電線の電流の大きさや構成, 配置により決まる。 計算による推定では日本の送電線直下の地上 $1 \mathrm{~m}$ にお る磁界の最大值は, 送電線が $20 \mu \mathrm{T}$ 程度, 配電線が $2 \mu \mathrm{T}$ 程度である。また, 日米の送電線を比較すると, 電線の配 置状況の違いにより，その直下の電界，磁界は，アメリカ の方がともに大きい傾向にある。

\section{2 居住環境における電磁界}

居住環境において人が受ける（曝露される）電磁界につ いては，国内，国外ともに調査はあまり行われていない。 電界については，発生源が建物の外にある場合は建物によ り遮へいされること, 居住環境内での発生源は主として電 圧が 100 200 V の屋内配線, 家庭電気製品であることか ら，それほど大きな值とならない。アメリカにおける測定 例として 5〜 $10 \mathrm{~V} / \mathrm{m}$ との報告がある。

磁界については, 建物外の発生源によるもののほかに, 屋内配線や家庭電気製品によるものがあり，北アメリカな どでは水道管を接地線として利用しているため,ここを流 れる電流も考慮する必要がある。人が受ける磁界は発生源 の種類, 発生源から距離などに依存し, 相当なばらつきが

表 2 自然界に存在する電磁界

\begin{tabular}{|c|c|c|c|}
\hline \multirow{5}{*}{$\begin{array}{l}\text { 電 } \\
\text { 界 }\end{array}$} & \multicolumn{2}{|c|}{ 周波数, $\mathrm{Hz}$} & 強度 (地表面における值) \\
\hline & \multirow{2}{*}{$0(\mathrm{DC})$} & 晴 & $80 \sim 180 \mathrm{~V} / \mathrm{m}$ \\
\hline & & 䪷雷時 & 最大 $30,000 \mathrm{~V} / \mathrm{m}$ \\
\hline & \multicolumn{2}{|l|}{$1 \sim 10$} & $10^{-2} \sim 10^{-3} \mathrm{~V} / \mathrm{m}$ \\
\hline & \multicolumn{2}{|c|}{ 50～60 (電力周波数) } & $10^{-4} \mathrm{~V} / \mathrm{m}$ \\
\hline 磁 & \multicolumn{2}{|c|}{$\begin{array}{l}0 \text { (地磁気) } \\
\text { ・日変化あり } \\
\text { ・磁気嵐時には不規則な変動 } \\
\text { あり }\end{array}$} & $\begin{array}{l}50 \mu \mathrm{T} \\
\text { 変動分：1 } 1 \mu \mathrm{T} \text { を超える場合 } \\
\text { がある }\end{array}$ \\
\hline & \multicolumn{2}{|l|}{$50 \sim 60$} & $10^{-6} \mu \mathrm{T}$ \\
\hline
\end{tabular}

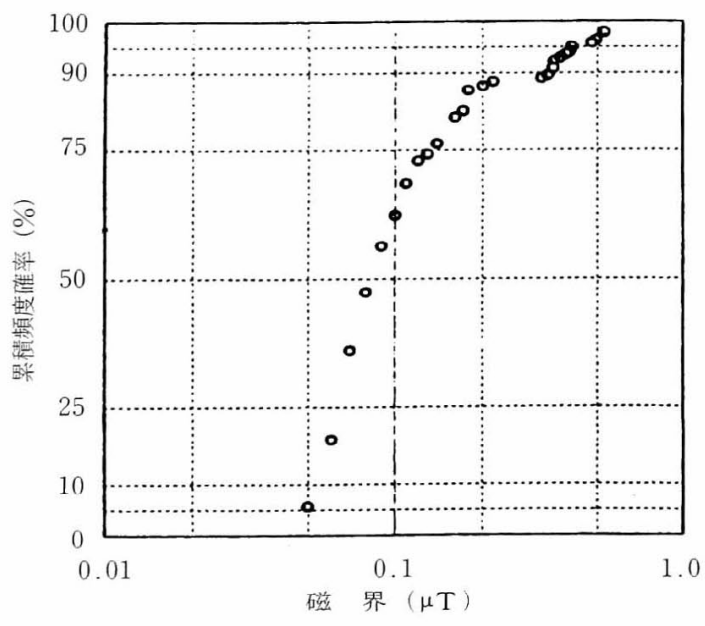

図 1 家庭内で受ける磁界の累積頻度確率の例
あるので, 消費電力から家庭内で受ける磁界を推定するこ とは難しい。日本でのデータとして, 家庭内で受ける磁界 の大きさの約 $90 \%$ までが $0.2 \mu \mathrm{T}$ 以下（図 1), 平均的な 曝露量は発生する最大值に比べて $1 / 40$ 以下との測定例が ある。

\section{4. 生物学的実験研究}

\section{1 生物学的研究の方法}

疫学研究で指摘された課題, すなわち電磁界が生体に影 響するかどうかについて, 多くの研究者が実験的研究に取 り組んでいる。実験は細胞や実験動物を用いて行われる が, 前者の細胞・分子を用いた研究はインビトロ実験, 後 者の動物を用いた研究はインビボ実験と呼ばれている。細 胞や組織の機能変化, 腫瘍の発生・促進, 免疫系, メラト ニン分泌, 脳の活動などを対象として, 数多くの研究が幅 広く行われている。

環境磁界は $\mu \mathrm{T}$ あるいはそれ以下のレベルであるが，そ のような微弱な磁界下での実験研究で何らかの影響を検出 することはほとんど不可能で，発がん性を確認あるいは否 定することは極めて難しいというのが実状である。

また，実験研究では，純粋に電磁界の影響だけを観察す る必要があるので, 外部環境に影響されない電磁界の発生 装置（図 2）が必要なこと，また，非常に長期間にわたる 観察が必要なことなど厄介な問題がある。さらに，生体影 響については実験手法による違いが生じる可能性もあるた め, 複数の機関による再現性の確認が必要である。

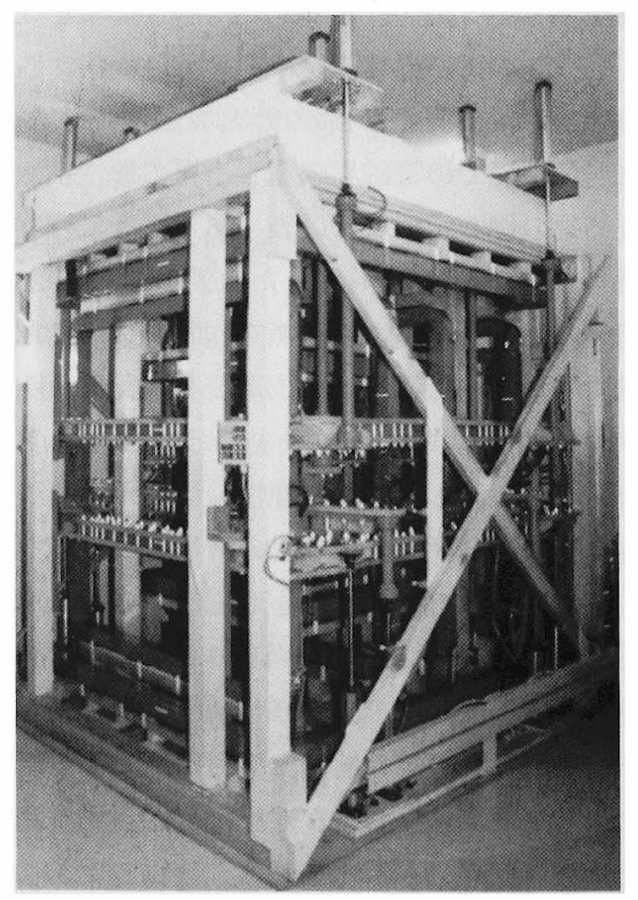

図 2 細胞実験用曝露装置の例 


\section{2 生物学的研究の結果}

「特別委員会」では，1991年以降1998 年初めごろまで に公表された学術論文を中心に調査した。電磁界の影響の 有無を明らかにするために, 細胞・分子レベルから動物レ ベルにわたり，多くの実験研究が行われている。体内への 誘導電流が $100 \mathrm{~mA} / \mathrm{m}^{2}$ 以上となるような大きな磁界（人 の身体の場合では外部の磁界が 5〜 50 mT 以上に相当) 人 の曝露では，インビトロ実験㧍よびインビボ実験に扔いて 生物学的変化が観察された例もあるが, 通常環境下で受け るレベル（例元ば $1 \mathrm{~mA} / \mathrm{m}^{2}$ 以下）での磁界䀧露では，再 現性のあるデータで有意な生物学的変化を認めたものはな い。

実験研究の一例を紹介すると，京都大学の宮越・武部な どによる研究では，通常の環境で最大とみられる強さの 10,000 倍以上の強力な商用周波磁界 $(400 \mathrm{mT})$ 下で実騃 を行い，遺伝子の発現の増大と突然変異誘発を確認してい る。これは世界で初めての明確な検出であるとされている が，極めて高い電磁界必要としており，遺伝子発現の促 進注一時的である。一方，5 $\mathrm{mT}$ での実験ではが九関連遺 伝子の発現促進はみら机ず，環境中の電磁界が人体に有害 である可能性は極めて小さいと結論づけている。

動物を対象にした研究では，ラットを用いた商用周波磁 界の生涯曝露実験が行われ，がん（白血病，脳腫痂など） の発生・促進について影響が認められないことが確認さ机 ている。低周波電磁界は電離作用がないことから, 直接 DNA を損傷し，がんを発生するような作用因子(イニシ エータ)ではないと考えられる。

一方, 化学発がん物質（DMBA）で発がん（皮覻がん， 乳腺腫崵, 肝臟がん、リンバ腫など）させた場合に，磁界 ががんの促進因子（プロモータ）として作用するか否かを 明らかにする実験研究が行わ机ている。こ机らの実験の中 では磁界への瀑露により乳腺腫演で変化が認められたとす る報告がある一方，そ机らを否定する報告もあり，この結 果の再現性を確認する研究が日本やアメリカで進行中であ る。

\section{5．電磁界に関する規制}

通常環境下に抢ける電磁界の健康への影響は認められて いないが，電磁界の值が非常に大きくなると，何らかの影 響をもたらすことも考えられるので，一部で規制が行かれ ており，電磁界を発生させる側ではその規制值の範团に入 るように設備などが設計されている。

日本に抢いては，商用周波電界について，送電線下に扔 いて静電誘導の感知に上る一般公毷の不快感索防止する観 点から, 田, 畑, 山林そのほかの人の往来が少ない場所を
除いて, 地表上 $1 \mathrm{~m}$ に抢ける電界強度を $3 \mathrm{kV} / \mathrm{m}$ 以下と するように決如れている（通産省令：電気設備に関する 技術基準（27 条)）。高周波については $10 \mathrm{kHz} \sim 300 \mathrm{GHz}$ の電波を対象として電波防護指針（郵政省電気通信技術 審議会答申 38 号: 平成 2 年 6 月, 同 89 号: 平成 9 年 4 月）があり引引き続き法的な強制力のもとで指針を運用す ベきかどうかの検討が行われている。

諸外国での商用周波電磁界に関する規制の実状はさまき まである。ドイツでは1997年から連邦排出影響防止法に 基づき，商用周波抢上び高周波電磁界が規制されている。 法的強制力のない任意の指針として運用されているものに はイギリスの例がある。NRPB（イギリス放射線防護評 議会）が 1993 年に示した声明で，公臬に適用される数値 （50 Hzに㧈いて）として電界強度 $12 \mathrm{kV} / \mathrm{m}$, 磁界強度 16 $G(1,600 \mu \mathrm{T})$ という值が示されている。

国際機関ではICNIRP（国際非電離放射線防護委員会） が1998 年 4 月に新たに指針を発表している。ICNIRPは 非電襍放射線からの人体防護方策を推進するために 1992 年に設立された国際委員会である。非政府機関であるが， WHO 扝上びILO (国際労働機関) との協力関係が公式 に承認されている。ICNIRP 指針は $300 \mathrm{GHz}$ 以下の電磁 界に適用されるが商用周波領域に扔いて公衆に適用される レベルとして， $50 \mathrm{~Hz}$ に対して電界 $5 \mathrm{kV} / \mathrm{m}$, 磁界 100 $\mu \mathrm{T}, 60 \mathrm{~Hz}$ に対して電界 $4.2 \mathrm{kV} / \mathrm{m}$, 磁界 $83.3 \mu \mathrm{T}$ とい う值が示されている。

\section{6.あとがき}

身の周りの電磁界と人の健康への影響に関して，できる だけ平易な゙解説を心掛けたが，この問題注専門の人たちが 学術的に正確を期して説明をしょうとすると，専門用語の 難解さも市って，一般の人にとって分かりにくいものとな つてしまう。またここれまでに行われた調查研究で，健康 への影響を認姉たものはないが，健康八の影響はないとい うことを証明するのは不可能に近い。そのようなことを理 解した上でこの問題についての正確な知識が広まること を望んでいる。本解説がその一助とな机ば幸いである。

世界各国で，現在も多くの研究が行かれており，日本国 内でも多くの実験研究が行われている。電気学会としても 引き続きこれらの研究の総合的な調查・評洒活動を続けて いる。またさらに詳しい内容について関心のある方は, 「特別委員会」の報告書「電磁界の生体影歇に関する現状 評洒と今後の課題」や，平易に解説した小册子「身の周り の電磁界と人の健康への影響」が笔気学会事務局より頒布 されているので参照されることを抢願いしたい。

(平成 11 年 3 月 16 日受付) 